cosmological principle. Again, he claims to deduce the Doppler effect from the manner in which the cosmological principle leads two or more observers to reconcile their clock readings, and hails this as evidence that the actual universe obeys the principle (indeed, Milne believes that God could not have made the universe otherwise). But obviously the Doppler effect could be detected if only one observer existed, so its derivation from the sociability of many must be fallacious. And so on.

This combination of paralysis of the reason with intoxication of the fancy is shown, if possible, even more strongly in Prof. P. A. M. Dirac's letter in NAture of February 20 last, in which he, too, appears as a victim of the great 'Universe' mania. In essence the argument is this. Large numbers need an entirely different type of explanation from small ones (since the number of pure numbers is infinite the distinction is meaningless, but meaning seems to be irrelevant to these considerations). If, from an indefinitely wide choice, we select a certain unit of time ("say the unit $e^{2} / m c^{3}$ "), the age of the universe according to one cosmological speculation is "about" equal to the square root of the number of protons in the universe according to another, and to the ratio of certain electronic forces. Hence we may take it as a "general principle" that all large numbers, etc. "In this way," adds Dirac, "we avoid the need of a theory."

The position must not be misunderstood. We are not dealing here with legitimate imagination transcending the temporary limits of exact demonstration. Nothing is easier and nothing is more deadly than to call for the stifling of all ideas that cannot here and now be proved of permanent value. But the question presented to us now is whether the foundation of science shall be observation or invention. Newton did not lack imagination, but he chose to examine pebbles rather than follow the Gadarene swine, even when the ocean before him was truth. Milne and Dirac, on the other hand, plunge headlong into an ocean of "principles" of their own making, and either ignore the pebbles or regard them as encumbrances. Instead of the induction of principles from phenomena we are given a pseudo-science of invertebrate cosmythology, and invited to commit suicide to avoid the need of dying. If anyone is uncertain about the place of imagination in science, let him compare Lord Rayleigh's discovery of argon with Dirac's discovery of the contemporary creation of protons which, according to The Times, "alters fundamentally our ideas of the structure of the universe and the nature of time".

Nor are we dealing with a mere skin disease which time itself will heal. Such ailments are familiar enough ; every age has its delusions and every cause its traitors. But the danger here is radical. Our leaders themselves are bemused, so that treachery can pass unnoticed and even think itself fidelity. It is the noblest minds that are o'erthrown, the expectancy and rose of the State which was lately so fair and in which there is now something so rotten that the very council of the elect can violate its charter and think it is doing science service. Five years hence we shall be celebrating the tercentenary of the death of Galileo and the birth of Newton. It rests with us whether we shall present to their memories a living monument of their own foundation or the resurrection hymn of their adversaries.

\title{
Rural England at the Royal Academy
}

$\mathrm{M}$ ANY of the subjects which enlisted the enthusiasm of British artists fifty years ago, notably the historical and military, have faded out of modern exhibitions, but the scenery of the English countryside and coast retains its attraction, and is fully represented in this year's Academy. Landscape, and especially English landscape, is the principal subject of the watercolour paintings. These, relegated to a side gallery, are generally viewed after the eye has become attuned to the larger and stronger oil paintings.

It may be well, therefore, for those interested in landscape to visit the South Rooms first. Here are studies of the coast of Cornwall, the Cotswolds, the Sussex Downs, the Fens and Yorkshire moors, and examples of historic architecture such as the castles of Richmond, Bamburgh and Holy Island. The country church as the principal feature in East Anglian landscape is well treated in "Morston, Norfolk" (889) by Mr. Harry Morley. The seasonal aspect of the country landscape is beautifully rendered in Mr. E. W. Haslehust's "Winter" (764), where yellow reed beds are reflected in still water and backed by a dark thicket of bare boughs. "March Landscape" (949), by Mr. Victor W. Burnand, is a careful rendering of the tracery of elm boughs seen against the evening sky. 
We come now to the oil paintings. The pictures entitled "The Evening Meal" (133) and "Pigs in a Barn" (332) by Mr. Frederick W. Elwell, are excellent studies of the interior of old timbered barns which, when the doors are open, give such opportunities for light and shadow. Mr. Fred Hall has a study of the same subject "In the Old Timbered Byre" (283). Mr. Edwin Byatt's "Mills at Outwood, Surrey" (164) shows the exterior view of roofs and gables of old barns and reminds us of the necessity for keeping in repair a picturesque feature, which when allowed to fall into dilapidation becomes a melancholy object in the countryside. It is perhaps from landscape paintings, rather than from direct observation, that the average person learns how decorative are the roofs and gables of old barns in the landscape of agricultural England. This is not entirely the average man's fault, for in actual fact there are few farmyards in which some part of the old roofs has not been repaired or replaced with unsuitable materials. The painter, however, can ignore these unsightly additions and represent the group of ridges and gables as they ought to be. There are a number of such studies in the present exhibition: "Afternoon on the Farm" (134) by Mr. Douglas P. Bliss, "Swanborough Pond" (266) by Mr. Vignoles Fisher, "A Sussex Lane in Winter" (650) by Miss D. H. de Carteret and "Essex Farmyard" (678) by Mr. Douglas Relf.

These studies lead one to consider the part of the landscape painter in the pressing task of preserving the scenery of rural England. The names of landscape painters figure very little on the councils of the numerous societies concerned in this important task, neither is it necessary that the exercise of their special talent should be interrupted by such activities. Rather should those engaged in the preservation of England's beauty study with care the outlook of the artist as embodied in contemporary exhibitions, and note particularly those artifices of composition by which disfigurements are passed over, and the yet more important devices by which the pictorial characters of a view are so enhanced as to carry the imagination from the actual to the infinite.

In the latter connexion, it is worth while to consider the titles which should be given to landscape pictures. The prevailing practice at the Royal Academy is to give the actual name of the locality or local feature without indication of the type of beauty which the picture embodies. Here and there, however, is a generalized landscape with an ideal title, as Mr. Reginald Hallward's "A Window on Eternity" (849). If the local names be retained in the case of a feature highly idealized, the artist provokes unfavourable comment; if it be not retained, the interest of association is lost.
I venture on the suggestion that in such cases the picture should be given the title of the locality and the sub-title of the pictorial quality which it embodies. As a case in point I may cite the very interesting study of "Early Morning: Corfe Castle" (456) by Mr. Stanley Royle. An essential pictorial character of a castle set upon a hill is the verticality of the lines which carry to infinity the gradient of the natural feature. But the walls of Corfe, undermined and blasted by Cromwell, have in parts been left leaning over, and so the ruin has lost considerably in effect. But in this painting the artist has straightened up the walls, and in the houses and church below has emphasized the vertical lines. Here, therefore, it might be well to give a sub-title which would explain to the general public that departure from photographic representation, which is in this case more than justified by the ideal attributes the picture embodies.

One of the most perfect landscapes in this year's Academy is Mr. Oliver Hall's "Greenholme Bridge, Westmorland" (215). The curve of the single arch, the upward sweep of the approaching road, the reflection in running water and background of trees make a delightful grouping of forms, and the subject suits the tonality which characterizes this artist's work. Of the pictures of inland waters the large "River Scene" (510) by Mr. Algernon Newton, shows the sigma curve which is one of the essential beauties of streams which wander across the plain. In the matter of coastal scenery we are once more indebted to Mr. Julius Olsson, among whose studies are "Opal Moon: Irish Coast" (317) and "The Storm Cloud" (169), an impressive picture of sea and sky.

The picturesque occupations of the countryside have received comparatively little attention, but two works at least deserve special attention, among pictures that by Miss L. Kemp-Welch of "The Lumber Team" (551) and among sculptures the very pleasing and unusual study "Lakeland Dalesman", equestrian statuette (1470) by Miss Ophelia Gordon.

The following portraits are of interest to the scientific fraternity, Sir Albert Seward (52) by Mr. Harold Knight, the late Brig.-General Sir Capel Holden, by Mr. P. Connard (158), Prof. T. B. Abell (290) by Mr. W. C. Penn, Mr. Sydney Evershed, by Mr. G. Harcourt (324), Sir George Hill, by Mr. J. Gunn (433), Sir Alexander Gibb (656) by Sir William Rothenstein, Sir Arthur Evans, charcoal drawing (1137) by Mr. Francis Dodd, and a marble bust of Sir Arthur (1451) by Mr. David Evans, a bust of Dame Helen Gwynne-Vaughan (1430) by Mr. Julian Allan and a stone bust of Prof. R. W. Reid (1435) by Sir W. Reid Dick.

VAUGHAN CORNISH. 